\title{
A nested polymerase chain reaction for the detection of genomic DNA of Myxobolus cerebralis in rainbow trout Oncorhynchus mykiss
}

\author{
Karl B. Andree ${ }^{1}$, Elizabeth MacConnell ${ }^{2}$, Ronald P. Hedrick ${ }^{1, *}$ \\ 'Department of Medicine and Epidemiology, School of Veterinary Medicine, University of California, Davis, \\ California 95616, USA \\ ${ }^{2}$ U.S. Fish and Wildlife Service, Fish Technology Center, Bozeman, Montana 59715, USA
}

\begin{abstract}
A nested polymerase chain reaction (PCR) test was developed to amplify a segment of the 18S rRNA gene from Myxobolus cerebralis, the agent causing whirling disease in salmonid fish. The PCR amplifies a $415 \mathrm{bp}$ amplicon that was identified by dideoxynucleotide terminated sequencing to be identical to the known $18 \mathrm{~S}$ rDNA sequence of $M$. cerebralis. There was no amplification of genomic DNA from 4 other myxosporean parasites of salmonid fish from the genus Myxobolus including $M$. arcticus, $M$. insidiosus, $M$. neurobius, and $M$. squamalis. The efficacy of the PCR test to detect early infections was demonstrated by amplification of the $415 \mathrm{bp}$ fragment from experimentally exposed rainbow trout Oncorhynchus mykiss at $2 \mathrm{~h}$ and at 1,2, and $3 \mathrm{wk}$ postexposure to actinosporean stages (triactinomyxons) of $M$. cerebralis. In contrast, standard microscopic examinations of stained tissue sections of the same fish used for PCR were less reliable in detecting the presence of the parasite. Additional examinations of fish 5 mo postexposure, after sporogenesis had occurred, found the PCR to be a more reliable indicator of infection than the pepsin-trypsin digest (PTD) method, paricularly when trout were experimentally exposed to low levels of the infectious stages of the parasite. The PCR was able to amplify to detectable levels the equivalent of a single sporoplasm of $M$. cerebralis as found in a tissue sample. This test improves the detection of $M$. cerebralis because it can detect the presence of the parasite: (1) in both hosts, (2) in all known stages of its life cycle, and (3) at lower thresholds than currently used diagnostic methods. Lastly, the PCR test is less susceptible to morphological misidentifications of the spores that can occur with current microscopic procedures.
\end{abstract}

KEY WORDS: Polymerase chain reaction - Ribosomal DNA - Myxobolus cerebralis

\section{INTRODUCTION}

Myxobolus cerebralis (Höfer 1903) is the myxozoan parasite responsible for whirling disease among several species of fish in the family Salmonidae $\left(\mathrm{O}^{\prime} \mathrm{Grod}\right.$ nick 1987). The agent, believed to have originated in central Europe and Asia, has presumably been dispersed with inter- and intracontinental movement of trout so that its worldwide distribution once included 21 countries and 19 states of the USA (Hoffman 1970. Wolf 1985). Myxozoans are well-known parasites of fish but many of their characteristics, including multi-

\footnotetext{
- Addressee for correspondence.

E-mail: rphedrick@ucdavis.edu
}

cellular developmental and sporogonic stages, and modes of transmission have only recently been described (El-Matbouli et al. 1992, 1995, El-Matbouli \& Hoffmann 1998). Beginning in 1983, Wolf \& Markiw published a series of papers describing experiments demonstrating that the life cycle of $M$. cerebralis involved 2 hosts, a salmonid fish and an aquatic oligochaete worm (Wolf \& Markiw 1981, 1984, Markiw \& Wolf 1983a, b, Wolf et al. 1986). M. cerebralis was clearly demonstrated to complete 2 separate developmental pathways in each host that culminated in a spore infectious for the other host. The spores that developed in both hosts had different morphology but both possessed key features demonstrated by all myxozoans; polar capsules containing coiled polar fila- 
ments and valves surrounding the viable sporoplasm cells. These developmental and spore stages were designated as myxosporean and actinosporean in their respective fish and worm hosts. The actinosporean forms, previously described as parasites of oligochaetes (Janiszewska 1955), were therefore united with the myxosporean forms for which infective stages for fish had previously been unknown (Corliss 1985, Kent et al. 1994).

Presumptive diagnoses of Myxobolus cerebralis depend on detection and correct identification of spores found in the fish host (Thoesen 1994). A confirmatory diagnosis relies on a demonstration in stained tissue sections that the spores or developmental stages are present in cartilage. Spores of other Myxobolus spp. with similar size and shape, however, are found in the skin, central nervous tissue and brain of salmonid fish (e.g. $M$. squamalis, $M$. kisutchi, $M$. neurobius, and $M$. arcticus) and these can complicate diagnostic examinations for $M$. cerebralis. $M$. cerebralis is unique among these Myxobolus spp. in being the only one to cause necrosis of cartilage.

The pepsin-trypsin digest (PTD) procedure and histology have been the 2 principal diagnostic approaches used to determine the distribution of Myxobolus cerebralis in captive and wild trout populations (Walker \& Nehring 1995). The PTD procedure aids in releasing and concentrating spores of the parasite from fish skeletal tissues (Markiw \& Wolf 1974). The recent outbreaks of whirling disease in wild trout in the western USA and the increased efforts to determine the distribution of the parasite have increased the use of the PTD method. While the PTD procedure is effective in detecting spores when these are present in higher concentrations, it is either ineffective or less sensitive when used to examine early infections (prior to spore formation) or lightly infected fish. The physical and chemical process of purifying the spores unfortunately destroys all prespore (extrasporogonic) stages of the parasite. Current diagnostic procedures for extrasporogonic stages require histological preparation and examination of trout tissues. Even when spores are detected by PTD and microscopy, they can be confused with Myxobolus spp. with similar spore morphology. Furthermore, some myxosporeans, even within a species, show varying morphology (Kreier 1994). Lastly, there is no accepted method for detection of the parasite in the oligochaete host or in its stages outside of either host.

Antibody-based detection procedures commonly used in diagnostic procedures have been attempted for Myxobolus cerebralis (Wolf \& Markiw 1975, Markiw \& Wolf 1978, Hamilton \& Canning 1988, Markiw 1989). Unfortunately, changing antigens with different developmental stages through the life cycle (Wolf \& Markiw 1984) and shared antigens between spores of differ- ent Myxobolus spp. complicate this approach. Also, multiple concurrent myxosporean infections occurring in the same fish (Hedrick et al. 1991) could confuse attempts to use fish serum antibodies for diagnostic purposes. The proper diagnosis of whirling disease is paramount in certain areas and consequences of a positive diagnosis of $M$. cerebralis may be severe (i.e. complete destruction of the stock). The need for accurate identification of the parasite in all stages of development has led us to pursue a DNA-based approach to detection of $M$. cerebralis.

Earlier work in our laboratory sequencing the $18 \mathrm{~S}$ rRNA gene of Myxobolus cerebralis provided the essential elements for the development of this DNAbased diagnostic test (Andree et al. 1997). To establish the practicality of such an approach for standard testing of fish stocks we developed and evaluated a PCR test in side by side comparisons with currently used diagnostic protocols. The PCR assay was compared with microscopic detection of $M$. cerebralis in stained tissue sections of experimentally exposed trout to demonstrate the ability of this test to detect early infections. In addition, we compared the PCR to the PTD procedure (Markiw \& Wolf 1974), for detection of the spores that develop later in infection. We demonstrated the specificity of this new DNA-based detection procedure for $M$. cerebralis by testing with 4 other Myxobolus spp. that are known parasites of salmonid fish. Lastly we demonstrated the ability of this test to discern infected from uninfected oligochaetes.

\section{MATERIALS AND METHODS}

Sources of spores. Spores of Myxobolus cerebralis for exposure studies were obtained directly from infected rainbow trout Oncorhynchus mykiss tissues from the Mt. Whitney Fish Hatchery (Lone Pine, California, USA). Spores were collected by homogenizing infected fish heads and passing the homogenates through gauze. The spores contained in the filtrate were used immediately. These spores were the source for a continuous culture of the parasite passed sequentially through the oligochaete and trout hosts. Actinosporean stages in the water from aquaria containing experimentally infected oligochaetes Tubifex tubifex were trapped on $20 \mu \mathrm{m}$ mesh screens. The actinosporean stages were resuspended in water, counted and diluted to the desired concentration for each exposure study.

The Myxobolus squamalis (Iversen 1954) spores were collected from the scale pockets of adult chinook salmon Oncorhynchus tshawytscha returning to the Nimbus Fish Hatchery, Rancho Cordova, California by Dr W. Cox (California Department of Fish and Game, 
Rancho Cordova). Cysts were ruptured and the contents collected in a $1.5 \mathrm{ml}$ microfuge tube. The spores $\left(3.0 \times 10^{7}\right)$ were then washed by multiple cycles of rinses in tap water and collected by low speed centrifugation $(500 \times g)$ for $5 \mathrm{~min}$.

Myxobolus arcticus (Schulman 1959) spores were collected from the hind brain tissue of heavily infected sockeye salmon Oncorhynchus nerka. This tissue was dissected from infected fish and provided to us by Dr M. Kent (Department of Fisheries and Oceans, Nanaimo, British Columbia, Canada). This tissue was homogenized then placed on a stepped Percoll gradient $(100 \%$, $75 \%, 50 \%$, and $25 \%$ Percoll) and centrifuged at $6000 \times g$ for $10 \mathrm{~min}$. The purified spores which formed a band were removed, rinsed once in tap water, and collected by low speed centrifugation $(500 \times g)$ for $5 \mathrm{~min}$.

Myxobolus insidiosus (Wyatt \& Pratt 1963) spores from juvenile chinook salmon at Aumsville Ponds, near Salem, Oregon, USA, were a kind gift from Drs J. Bartholomew and A. Amandi (Oregon State University, Corvallis). These spores $\left(2.0 \times 10^{7}\right)$ were dissected from infected skeletal muscle and cleaned by the same procedure described for $M$. arcticus but using sucrose rather than Percoll gradients.

Myxobolus neurobius (Schuberg \& Schröder 1905) spores, purified from neural tissue of infected rainbow trout Oncorhynchus mykiss from the upper Owens River near Crestview, California, were provided by John Modin (California Department of Fish and Game, Rancho Cordova). The infected tissue was processed and the spores purified as described for $M$. arcticus

Source of fish. Rainbow trout were acquired from a commercial rainbow trout egg producer. Eggs were received in the 'eyed' stage and hatched in our laboratory facilities. They were raised in $15^{\circ} \mathrm{C}$ well water and fed a commercial trout diet, initially with automatic feeders and later twice daily by hand.

Source of oligochaete worms. Oligochaete worms were brought to the lab from the Mt. Whitney Fish Hatchery, where they were obtained from the settling ponds. This site is enzootic for whirling disease in rainbow trout. Worms were housed in static aquaria (5 l) with well water $\left(15^{\circ} \mathrm{C}\right)$ and sterilized sand substrate. The aquarium water was monitored for releases of triactinomyxons during water changes every third day. After releases of triactinomyxons had ceased, spores of Myxobolus cerebralis obtained from infected trout were placed onto worms ( $10^{7}$ spores $/ 20 \mathrm{~g}$ of worms $)$ to initiate infections. Triactinomyxons for experimental infection trials with rainbow trout were harvested for PCR studies at approximately $14 \mathrm{wk}$ following exposure to spores. Worms examined by PCR were obtained from this culture at $14 \mathrm{wk}$ and from a control population of worms to which $M$. cerebralis spores had not been added.
Experimental exposures of trout. Triactinomyxon spore stages of Myxobolus cerebralis were collected by filtration of the water of aquaria harboring $M$. cerebralis infected oligochaete worms. Filtration was accomplished using $10 \mu \mathrm{m}$ netting fitted into a plastic funnel. Fish were placed in $500 \mathrm{ml}$ of water with the appropriate number of spores for the given dosage in each experiment. After $2 \mathrm{~h}$ the fish were removed from the exposure container and placed back into $20 \mathrm{l}$ aquaria receiving flow-through $\left(0.5 \mathrm{l} \mathrm{min}^{-1}\right) 15^{\circ} \mathrm{C}$ well water for the duration of the experiment.

Testing for cross reactivity. After searching the sequence alignment of Myxobolus cerebralis, $M$. arcticus, $M$. insidiosus, $M$. neurobius, and $M$. squamalis, we found 4 regions of heterologous sequence in the $18 \mathrm{~S}$ rRNA gene of $M$. cerebralis which, according to computer simulation, would not hybridize with the other Myxobolus spp. 18S rRNA genes. To confirm this, genomic DNA (300 ng) from each species was isolated and tested using the newly developed nested PCR for $M$. cerebralis

Determining limits of detection. Freshly isolated triactinomyxon spore stages of Myxobolus cerebralis were placed in a petri dish on an inverted microscope. Using a $10 \mu$ pipette, individual triactinomyxons were picked up and placed in a $200 \mu l$ tube. After tubes containing the desired number of triactinomyxons had been obtained, the volume was brought to $10 \mu \mathrm{l}$ with $0.5 \times$ lysis buffer $(100 \mathrm{mM} \mathrm{NaCl}, 10 \mathrm{mM}$ Tris pH 7.6, $10 \mathrm{mM}$ EDTA, $0.2 \% \mathrm{SDS}, 0.2 \mathrm{mg} \mathrm{ml}^{-1}$ proteinase $\mathrm{K}$ ) and they were placed in a thermal cycler and heated to $55^{\circ} \mathrm{C}$ for $1 \mathrm{~h}$. Two sets of samples were obtained, each containing $20,10,5$, or 1 triactinomyxon. To each tube in 1 set of samples, $300 \mathrm{ng}$ of uninfected rainbow trout genomic DNA was added to mimic infected trout tissues with a known dose of triactinomyxons.

A single triactinomyxon contains approximately 64 sporoplasm cells (El-Matbouli \& Hoffman 1998). To test the ability of the PCR test to detect a single Myxobolus cerebralis cell, another tube containing DNA from only 1 triactinomyxon was diluted 64 -fold to represent the equivalent of a single sporoplasm cell. A second tube containing the diluted sample from the triactinomyxon stage and $300 \mathrm{ng}$ of uninfected host DNA was also tested to mimic a tissue sample containing a single cell of $M$. cerebralis.

Early detection study. Sporogenesis of Myxobolus cerebralis takes 2 to 3 mo to initiate at the water temperature of $15^{\circ} \mathrm{C}$ used in our study (El-Matbouli et al. 1995). In early infections, in the absence of spores, the diagnosis of $M$. cerebralis is made by microscopic examinations of stained sections of either whole fish, or the cranial portion of larger fish. In a comparison of PCR to microscopy, 2 wk old rainbow trout $(0.1 \mathrm{~g}$ av. wt) were exposed to 50000 triactinomyxons per fish. 
Two groups of 25 fish were prepared, one for the exposure to triactinomyxons, and the other for a shamexposure. Five fish were collected from each group at each time point. Fish were collected at $2 \mathrm{~h}, 1 \mathrm{wk}, 2 \mathrm{wk}$, and $3 \mathrm{wk}$ postexposure.

At each sampling, the fish were cut along a midline sagittal plane using a clean razor blade. The blade and the work surface were changed for each fish. Half of the entire fish was placed in a microfuge tube for DNA extraction and the other half of the fish was placed into $10 \%$ neutral buffered formalin for later histological preparation and microscopic examination. Tissue sections were made from paraffin embedded whole fish and stained with hematoxylin and eosin. One slide was examined for each fish for $5 \mathrm{~min}$ at $200 \times$ for the presence of developmental stages of Myxobolus cerebralis. The sample used for DNA extraction was homogenized in the microfuge tube using a Konte Pellet Pestle (Fisher Scientific, Pittsburgh, PA, USA). After homogenization, the DNA was extracted following the 'Mouse Tail Protocol' from the Qiamp Blood and Tissue Kit (Qiagen, Inc., Chatsworth, CA).

Late stage detection study. In a comparison of PCR to PTD detection of Myxobolus cerebralis, 2 groups of rainbow trout were examined that had been experimentally exposed to different levels of triactinomyxons. Fish were 8 wk old ( $3.6 \mathrm{~g}$ av. wt) at the onset of the experiment. The high dose exposure group received 2000 triactinomyxons per fish and the low dose exposure received 200 triactinomyxons per fish. Groups of 20 fish were exposed to each dose and a third group received a sham-exposure. All fish were sacrificed 5 mo postexposure. Fish ranged in size from 6 to $10 \mathrm{~cm}$ ( $7.9 \mathrm{~g}$ av. wt). Each fish was cut along a midline sagittal plane as described previously. With these larger fish, a $6 \mathrm{~mm}$ diameter skin biopsy punch (Miltex Instrument Company, Inc., Lake Success, NY, USA) was used to remove a plug of tissue from one half of the head that encompassed the caudal ventral portion of the skull and the auditory capsule. The other half of the head anterior to the dorsal fin was saved for the PTD method of extracting and enumerating myxosporean stage spores. The plug of tissue was placed in a $1.5 \mathrm{ml}$ microfuge tube and homogenized using a clean Konte Pellet Pestle. The sample DNA was extracted from the homogenized tissue following the Mouse Tail Protocol' from the Qiamp Blood and Tissue Kit.

DNA extractions, sequencing, and alignments of rDNA. DNA extractions were carried out as described for myxosporeans (Andree 1997). DNA isolation from whole tissue and from transformant bacterial cells was performed as described by Sambrook et al. (1989). The $18 \mathrm{~S}$ rDNA sequencing and alignments of sequences were performed as described previously (Andree et al. 1997)
Primer selection and oligonucleotide synthesis. Primers MX5 and MX3, for the generic amplification of Myxobolus spp. 18S rDNA, were chosen from homologous regions identified after alignment of the $18 \mathrm{~S}$ rDNA sequences from $M$. cerebralis, $M$. insidiosus, and $M$. squamalis. Primers for the specific amplification of $M$. cerebralis $18 \mathrm{~S}$ rDNA (Fig. 1) were chosen from unique regions of sequence composition as compared to 5 Myxobolus spp. from salmonid fish ( $M$. cerebralis, $M$. insidiosus, $M$, neurobius, $M$. arcticus, and $M$. squamalis) we have sequenced (Andree et al. in press). The selected primer sequences were tested for possible secondary structure, self-complementarity, and absence of cross reactions to host sequences using 'Amplify' software (University of Wisconsin Genetics, Madison, WI, USA). Oligonucleotides, once synthesized, were diluted in water to working concentrations for PCR and DNA sequencing, 20 and 4 pmol $\mu^{-1}$, respectively.

Primer sequences:

MX5 5'-CTGCGGACGGCTCAGTAAATCAGT-3'

MX3 5'-CCAGGACATCTTAGGGCATCACAGA-3'

Tr5-16 5'-GCATTGGTTIACGCTGATGTAGCGA-3'

Tr5-17 5'-GCCCTATTAACTAGTTGGTAGTATAGAAGC-3'

Tr3-16 5'-GAATCGCCGAAACAATCATCGAGCTA-3'

Tr3-17 5'-GGCACACTACTCCAACACTGAATTTG-3'

PCR amplification of rDNA. All the amplifications were performed in standard $50 \mu$ reactions containing $10 \mathrm{mM}$ Tris- $\mathrm{HCl} \mathrm{pH} 8.3$ (at $25^{\circ} \mathrm{C}$ ), $50 \mathrm{mM} \mathrm{KCl}, 1.5 \mathrm{mM}$ $\mathrm{MgCl}_{2}, 0.001 \% \mathrm{w} / \mathrm{v}$ gelatin, $400 \mu \mathrm{M}$ dNTP's, $5 \mu \mathrm{M}$ tetramethyl ammonium chloride, $40 \mathrm{pmol}$ of each

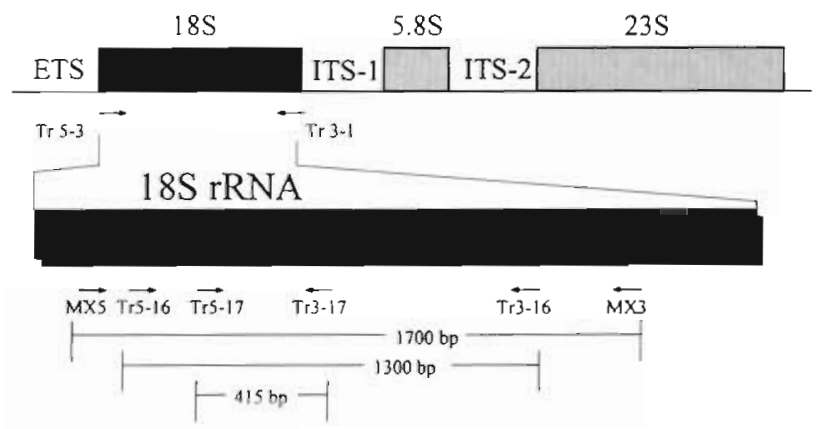

Fig. 1. Diagram of a eukaryotic ribosomal DNA motif showing the location of the diagnostic primers for the PCR detection of Myxobolus cerebralis. Primers Tr 5-16 and Tr 3-16 are used in the first round of amplification generating an amplicon of $\sim 1300 \mathrm{bp}$. The second round of amplification uses primers $\operatorname{Tr} 5-17$ and $\operatorname{Tr} 3-17$, generating an amplicon of $415 \mathrm{bp}$. Primers $\operatorname{Tr} 5-3$ and $\operatorname{Tr} 3-1$ were used in the amplification of the full length 18S rRNA gene for the initial sequencing of the $18 S$ IRNA gene of $M$. cerebralis. Primers $M \times 5$ and $M X 3$ were used in the amplification of a 1700 bp tragment of the rRNA gene from $M$. arcticus, $M$. insidiosus, $M$. neurobius, and $M$. squamalis 
primer, and $2 \mathrm{U}$ Taq polymerase. The PCR thermal cycler used was a model PTC-100 (MJ Research, Watertown, MA, USA).

The 1700 bp fragment of the 18S rDNA from Myxobolus neurobius, $M$. insidiosus, $M$. arcticus, and $M$. squamalis was amplified using primers MX5 and MX3. Forty cycles of $1 \mathrm{~min}$ at $95^{\circ} \mathrm{C}$, followed by 2 min at $45^{\circ} \mathrm{C}$, followed by $4.5 \mathrm{~min}$ at $72^{\circ} \mathrm{C}$ were used in the amplification. The amplification cycles were preceded by a denaturation step where samples were held at $95^{\circ} \mathrm{C}$ for $5 \mathrm{~min}$. The thermal cycler program finished with an extended elongation step where samples were held at $72^{\circ} \mathrm{C}$ for $10 \mathrm{~min}$.

The 18S rDNA of Myxobolus cerebralis was amplified with a nested PCR developed using known sequences obtained from the actinosporean stage of $M$. cerebralis. In the first round, primers $\operatorname{Tr} 5-16$ and $\operatorname{Tr} 3-16$ were used (Fig. 1). In the second round, primers $\operatorname{Tr} 5-17$ and $\operatorname{Tr} 3-17$ were used. Thirty-five cycles of $1 \mathrm{~min}$ at $95^{\circ} \mathrm{C}$, followed by $2.5 \mathrm{~min}$ at $65^{\circ} \mathrm{C}$, followed by $1.5 \mathrm{~min}$ at $72^{\circ} \mathrm{C}$ were used in the amplification. The amplification cycles were preceded by a denaturation step where samples were held at $95^{\circ} \mathrm{C}$ for $5 \mathrm{~min}$. The thermal cycler program finished with an extended elongation step where samples were held at $72^{\circ} \mathrm{C}$ for $10 \mathrm{~min}$.

The single round PCR test for detection of Myxobolus cerebralis was performed using either the primer $\operatorname{Tr} 5-16$ or $\operatorname{Tr} 5-17$ as the forward primer and $\operatorname{Tr} 3-17$ as the reverse primer. All other conditions remained as described above for the nested PCR test

The myxosporean $18 \mathrm{~S}$ rDNA genes were cloned into pNoTA using the Prime PCR Cloner Kit (5 Prime > 3 Prime, Boulder, CO, USA) following the manufacturer's protocols

Enumeration of myxosporean stage spores using the pepsin-trypsin digest method. The following protocol has been modified from procedures developed in the laboratory of Dr T. Baldwin (Washington State University, Pullman, WA) and Dr L. Chittum (Colorado Division of Wildlife, Brush, CO). Each head was placed in a labeled urine cup with a screw cap lid with $20 \mathrm{ml}$ of lukewarm tap water. The containers were placed in a shaker incubator heated to $50^{\circ} \mathrm{C}$ until the tissue separated easily from the cartilage and bone. Three clean glass beads were added to each container, then the container was shaken vigorously, though briefly, to release flesh from cartilage and bones. The sample was decanted through a urinary filter into a $50 \mathrm{ml}$ centrifuge tube. All of the cartilage and bone was picked from the urine cup and from the urine filter and transferred into a clean $50 \mathrm{ml}$ centrifuge tube. The urine cup and filter were rinsed with several small volumes of water to recover as many spores as possible. The tubes with the collected rinse water were centrifuged $10 \mathrm{~min}$ at $1305 \times g$ to pellet spores.
Ten milliliters of $0.5 \%$ pepsin was added to the cartilage/bone fragments and the tubes were placed in a shaker incubator set at $37^{\circ} \mathrm{C}$ and incubated for 1 to $3 \mathrm{~h}$. After digestion was complete, the samples were centrifuged at $1305 \times g$ for $10 \mathrm{~min}$. The pellet was resuspended in $5 \mathrm{ml}$ water, then $5 \mathrm{ml}$ of $0.1 \%$ trypsin was added. The $\mathrm{pH}$ was adjusted to between 8 and 8.5 with $0.1 \mathrm{~N} \mathrm{NaOH}$. The tubes were placed in a shaking incubator at room temperature for $30 \mathrm{~min}$. When the digestion was complete, $1 \mathrm{ml}$ of bovine calf serum was added to each tube to neutralize the trypsin. The contents of each tube were then poured through a fresh urine filter into the centrifuge tube with the pelleted washes from the same sample, as described above. The digestion tube was rinsed twice with $10 \mathrm{ml}$ aliquots of water and poured through the filter to wash it and to collect as many of the spores as possible. Spores from the rinse solutions were centrifuged for $10 \mathrm{~min}$ at $1305 \times g$ and resuspended with spores from the earlier preparation in $1 \mathrm{ml}$ of $10 \%$ neutral buffered formalin with $0.00025 \%$ methylene blue. The sample was thoroughly mixed with a Pasteur pipette, then loaded on both sides of a hemocytometer counting chamber for spore enumeration.

\section{RESULTS}

\section{PCR amplification of Myxobolus cerebralis}

The DNA from tissues of experimentally infected rainbow trout and experimentally infected oligochaetes was screened for amplification by PCR of a $415 \mathrm{bp}$ DNA fragment corresponding to the presence or absence of Myxobolus cerebralis. Sham-exposed fish and worms served as negative controls for each experiment. A total of 30 oligochaetes were tested using the nested PCR. All of the 15 experimentally infected worms tested positive while an equal number of control oligochaetes tested negative (not shown). A $415 \mathrm{bp}$ amplicon was found from most experimentally exposed worms but from no unexposed worms. The identity of the amplified DNA was confirmed by automated sequencing (data not shown). A 510 bp band was often detected in samples from positive fish, but was never observed in the absence of the $415 \mathrm{bp}$ amplicon. The $510 \mathrm{bp}$ band results from carry-over of the round I primer Tr 5-16 into the round II PCR which forms an amplicon with the round II primer $\operatorname{Tr} 3-17$ (Fig. 1). The appearance of this $510 \mathrm{bp}$ amplicon is somewhat concentration dependent in that it appears less frequently in control samples that are diluted or in experimentally infected fish samples with fewer parasites. 


\section{Testing with other myxosporeans}

The cross reactivity of the PCR as tested with genomic DNA from Myxobolus spp. ( $M$. arcticus, $M$. insidiosus, $M$. neurobius, and $M$. squamalis) from salmonids demonstrated that only $M$. cerebralis yielded a 415 bp amplicon (Fig. 2).

\section{Limits of detection}

The limits of detection for this PCR test were examined using DNA isolated from purified triactinomyxons alone or as mixed with $300 \mathrm{ng}$ of uninfected rainbow trout DNA. Samples contained 20, 10, 5, or 1 triactinomyxons. Additionally, the DNA from a single triactinomyxon was diluted 64-fold to approximate the equivalent of a single cell of Myxobolus cerebralis and tested with or without the added host DNA. In a single round test using primers Tr 5-17 and $\operatorname{Tr} 3-17$ (Fig. 1) nearly all the samples tested positive, but noticeable interference was observed from the addi-

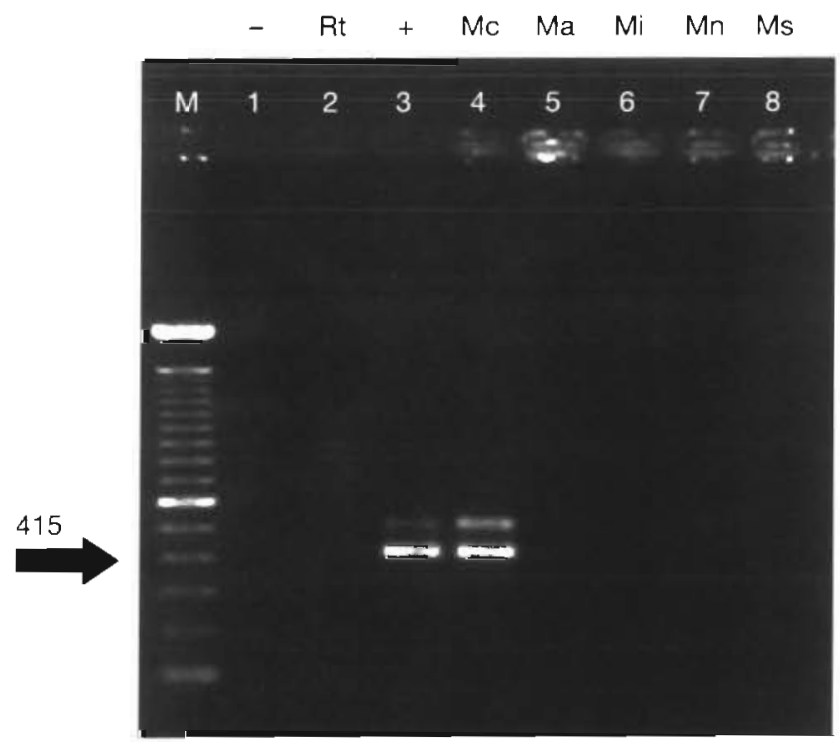

Fig. 2. Cross-reactivity trial with other Myxobolus spp. with the nested PCR test for detection of $M$. cerebralis. Lane $M$ is the $100 \mathrm{bp}$ ladder molecular weight standard. Lane 1 is a negative control (-) containing the PCR reagents alone. Lane 2 is uninfected rainbow trout genomic DNA (Rt). Lane 3 is $10 \mathrm{ng}$ of the positive control plasmid ( + ) p18Tr29, which carries a clone of the 18S rRNA gene of $M$. cerebralis. Lanes 4 to 8 are genomic DNA samples from, respectively, $M$. cerebralis (Mc). $M$. arcticus (Ma), $M$. insidiosus (Mi), $M$. neurobius ( $\mathrm{Mn}$ ), and M. squamalis (Ms) tion of $300 \mathrm{ng}$ host DNA to the sample containing DNA from the equivalent of a single $M$. cerebralis cell (Fig. 3). The interference by the addition of host tissue, as observed in the single round test, might lead to false negative results. To evaluate this possibility, experimentally infected fish given a low dose exposure of triactinomyxon spores (200 triactinomyxon spores per fish) were tested using both the single round test and the nested test. Two out of 20 fish tested positive with the single round test (data not shown) while 7 out of 20 tested positive with the nested test (Table 1).

Table 1. A comparison of the nested PCR test to current methods (PTD and histology) for detection of late and early infections in rainbow trout following experimental exposures to triactinomyxons of Myxobolus cerebralis

\begin{tabular}{|c|c|c|c|c|}
\hline \multirow{2}{*}{$\begin{array}{l}\text { Early } \\
\text { detection }\end{array}$} & \multicolumn{4}{|c|}{ Time postexposure } \\
\hline & $2 \mathrm{~h}$ & $1 \mathrm{wk}$ & $2 w k$ & $3 \mathrm{wk}$ \\
\hline Histology & $2 / 5$ & $0 / 5$ & $0 / 5$ & $0 / 5$ \\
\hline PCR & $5 / 5$ & $5 / 5$ & $5 / 5$ & $5 / 5$ \\
\hline $\begin{array}{l}\text { Late } \\
\text { detection }\end{array}$ & $\begin{array}{c}200 \\
\text { spores/fish }\end{array}$ & sl & $\begin{array}{c}2000 \\
\text { spores/fish }\end{array}$ & Control \\
\hline PTD & $1^{d}$ & & $20^{b}$ & 0 \\
\hline PCR & 7 & & 20 & 0 \\
\hline
\end{tabular}




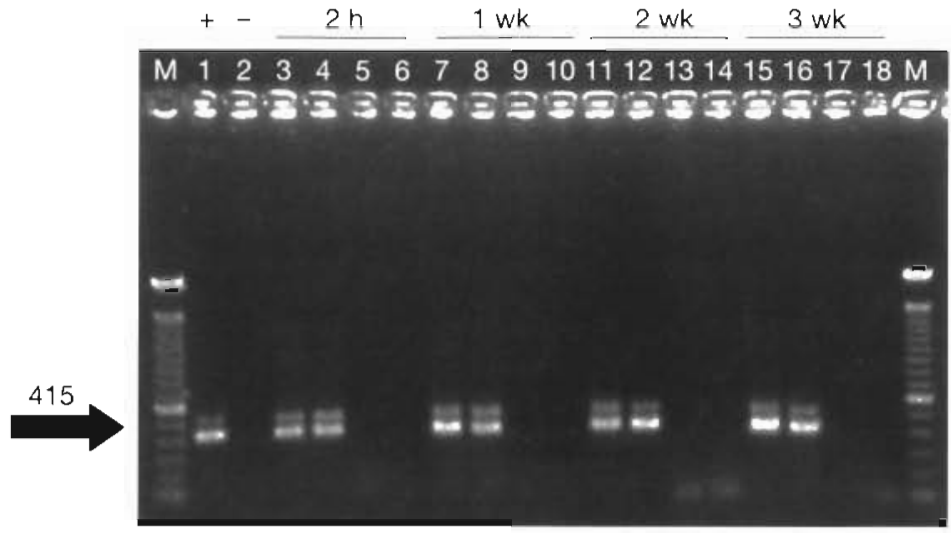

Fig. 4. Detection of Myxobolus cerebralis by PCR in the early stages of infection. Only 2 out of 5 samples from each group are shown here Lane $M$ is the 100 bp ladder molecular weight standard. Lane 1 is $10 \mathrm{ng}$ of the positive control plasmid. Lane 2 is a negative control containing the PCR reagents alone. Lanes 3 and 4 are samples from exposed fish while lanes 5 and 6 are sham-exposed collected 2 h postexposure. Lanes 7,8 and 9, 10 are the exposed and sham-exposed fish, respectively, collected $1 \mathrm{wk}$ postexposure. Lanes 11,12 and 13 , 14 are the exposed and sham-exposed fish, respectively, collected 2 wk postexposure. Lanes 15, 16 and 17, 18 are the exposed and sham-exposed fish, respectively, collected $3 \mathrm{wk}$ postexposure

\section{DISCUSSION}

The presumptive diagnosis of Myxobolus cerebralis, the causative agent of salmonid whirling disease, currently relies on isolation and then identification of spores, usually by the PTD method, from fish skeletal elements (Markiw \& Wolf 1974). A confirmatory diagnosis of $M$. cerebralis follows if spores are observed within cranial cartilage of stained tissue sections from infected fish (Thoesen 1994). Unfortunately, the diagnosis of whirling disease and $M$. cerebralis can be confused both by gross and behavioral signs due to the presence of other bacterial or parasitic infections, including myxosporeans with similar spore morphology (Margolis et al. 1996). Current diagnostic procedures are inadequate in detecting all stages of infection (early and late) in both the fish and oligochaete hosts. In addition, due to their labor, time and costs, the PTD and histology examinations are viewed as detection techniques that require improvement. These concerns led us to develop new approaches to detection of $M$. cerebralis using the PCR.

\section{Early detection tests}

All of the exposed fish tested positive with the nested PCR at $2 \mathrm{~h}, 1,2$, and $3 \mathrm{wk}$ postexposure (Fig. 4). No sham-exposed fish tested positive. Results from the histological examination of this same group of samples demonstrated only 2 positive with identifiable developmental stages of Myxobolus cerebralis in their tissues at $2 \mathrm{~h}$ postexposure (Table 1). Although assumed to be present, extrasporogonic stages in the nerves were not detected by microscopy in the 1,2 , and $3 \mathrm{wk}$ postexposure groups.

\section{Late detection tests}

Fish exposed to the high dose of triactinomyxons (2000 triactinomyxons/fish) and tested by the nested PCR at 5 mo postexposure all tested positive. Similarly, all of these fish had detectable levels of spores (Table 1). In contrast, in the low dose exposure group (200 triactinomyxons/fish) that was tested by the nested PCR at $5 \mathrm{mo}$ postexposure, only 7 out of 20 tested positive by PCR (Table 1). Only 1 fish from this low dose group had detectable spore counts. Of the 20 control unexposed fish tested, none were found positive by the nested PCR. No spores were detected among any control (unexposed) trout examined by the PTD method.
The changing antigenic mosaic presented by developmental stages of the same organism in radically different morphological forms (actinosporean and myxosporean) have made the use of either monoclonal or polyclonal antibody probes problematic. In contrast, genomic DNA represents an invariable target for detection of a given species. We have cloned and sequenced the $18 \mathrm{~S}$ IRNA gene of 4 myxosporeans known to infect salmonids to design primer sequences unique for detecting only Myxobolus cerebralis (Andree et al. 1997, Andree et al. in press). Testing by computer analysis of the primers we designed for $M$. cerebralis with sequences obtained from $M$. neurobius, $M$. insidiosus, $M$. squamalis and $M$. arcticus found no homologous sites for hybridization. This was confirmed by performing PCR tests on genomic DNA isolated from all of the above mentioned species and from uninfected rainbow trout (Fig. 2). Similarly, tests with DNA from uninfected oligochaetes have been negative (data not shown).

The threshold of detection of a single round PCR test using primers $\operatorname{Tr} 5-17$ and $\operatorname{Tr} 3-17$ was determined using samples of purified triactinomyxon genomic DNA mixed with or without $300 \mathrm{ng}$ of uninfected rainbow trout genomic DNA. Nearly all samples tested positive, though when the ratio of parasite to host DNA was low, results become equivocal (Fig. 3). In contrast, the nested PCR test detected Myxobolus cerebralis at all levels examined (not shown) and this test was 
therefore used in subsequent comparisons of PCR to currently accepted histological and PTD detection methods for the parasite.

Evaluation of the nested PCR test to diagnose individuals in early infections with Myxobolus cerebralis demonstrated all exposed fish to be positive while an equal number of individuals from the control group were all negative. We were able to detect the infection as early as $2 \mathrm{~h}$ postexposure (Fig. 4 , Table 1). While the experimental exposures given to these fish were relatively high, early developmental stages were visible by microscopy in only 2 fish at $2 \mathrm{~h}$, but not at 1,2 or $3 \mathrm{wk}$ postexposure. Extrasporogonic stages expected to be present in nerves were not detected in our samples (El-Matbouli et al. 1995). Our experience is that these are often hard to detect in many experimentally exposed fish (unpubl. results) unless the dose of triactinomyxons for exposure is very high (i.e. 100000 triactinomyxons/fish or greater).

Detection of Myxobolus cerebralis at later stages of infection relies heavily on identification of spores isolated by the PTD method. The PCR detected more positives among the experimentally exposed individual fish than did either of the currently used diagnostic methods (Table 1). This preliminary investigation demonstrates the increased ability of the PCR to detect fish that harbor few to no spores of $M$. cerebralis as determined by current PTD methods

The nested PCR test for the detection of Myxobolus cerebralis relies on 2 sets of oligonucleotides to amplify a 415 bp fragment of the 18S rRNA gene from the parasite. Attempts to modify the test to a single round of amplification were compared to the nested test by assaying the samples from the low dose exposure group (200 triactinomyxons/fish) mentioned above. The primers $\operatorname{Tr} 5-16$ and $\operatorname{Tr} 3-17$ were used in this single round PCR. The primer Tr 5-16 was chosen as the forward primer in this single round test for its apparent ability to bind more specifically to target sequences than the second forward primer Tr 5-17. These differences between forward primers were made apparent while investigating the appearance of a second amplicon of 510 bp (Figs. 2 \& 4). When both forward primers $\operatorname{Tr} 5-16$ and $\operatorname{Tr} 5-17$ were used together with the reverse primer $\operatorname{Tr} 3-17$ in a single round of amplification, only the amplicon from $\operatorname{Tr} 5-16$ and $\operatorname{Tr} 3-$ 17 (510 bp) was produced even when primer Tr 5-16 was present in a 5 -fold lower concentration (data not shown). Although use of the single round PCR test using primers $\operatorname{Tr} 5-16$ and $\operatorname{Tr} 3-17$ shortened the time and expense of the assay, it was clearly less sensitive in detecting $M$. cerebralis. Using this single round of amplification, only 2 out of 20 from the low dose exposure group were detected as positive. While this nested PCR is not a quantitative test of the concentration of $M$. cerebralis DNA in a tissue sample, the appearance of the extra band of $510 \mathrm{bp}$ (from primers Tr 5-16 and Tr 3-17) correlates with higher concentrations of the target sequence. Conversely, this 510 bp band frequently disappears when target DNA concentrations are low (data not shown). The 510 bp band appears due to carry-over of the round 1 primers to the round 2 reaction. This can be remedied by reducing the concentration of primers $\operatorname{Tr} 5-16$ and $\operatorname{Tr} 3-16$ in the first round reactions (not shown).

There are several advantages of this new nested PCR test for Myxobolus cerebralis. They include direct visualization of specific bands on ethidium bromide stained gels, greater sensitivity than current diagnostic methods and elimination of the need for confirmation of the identity of the product from a single round test by such means as Southern blotting or sequencing. Disadvantages of the new nested PCR test as currently developed are the continued need to sacrifice the fish and the high sensitivity and its incumbent susceptibility to contamination.

Preliminary testing suggests the new PCR assay effectively distinguishes Myxobolus cerebralis from 4 other Myxobolus spp. potentially found in salmonids. However, additional Myxobolus spp. (e.g. M. kisutchi) and other myxosporeans remain to be tested.

As currently designed the sample collection procedures for the PCR test may not be appropriate for the sampling of large mature fish. Alternatively, taking several small and carefully chosen samples of tissue from the whole head may compensate for this problem.

With respect to early infections, the PCR provides a new and sensitive approach to detection of the earliest development stages as present in the skin, nerves, and cartilage, well before onset of clinical signs. This might be particularly useful in studies with sentinel fish where brief exposures would provide indications of the presence of the infectious stages in the watershed at specific time points and locations. This information is useful for managerial efforts to stem the spread of the disease.

The greatest asset of the PCR test is its ability to detect all possible stages of the parasite including both actinosporean and myxosporean stages (El-Matbouli. et al. 1995, El-Matbouli \& Hoffman 1998). These parasite stages can be found in either host or in water but presumably also in sediments, feces of fish-eating animals, and inanimate objects that may serve to transport infective stages. The ability to detect the parasite in the oligochaete host, Tubifex tubifex (Markiw \& Wolf 1983 , Wolf \& Markiw 1986), provides the first specific test for infections in this host. The sampling of oligochaetes, rather than, or in combination with, fish, can now be utilized when determining the distribution of Myxobolus cerebralis. 
An additional application of the PCR primers is their use as molecular probes for in situ hybridization to visualize stages of the parasite and to identify any particular tissue tropisms, portals of entry, or previously unrecognized developmental stages. This approach has already shown promise in our laboratory (Antonio et al. in press).

While this new PCR test for Myxobolus cerebralis has shown great promise in laboratory trials, its application for field-testing/sampling is just now beginning. We suspect that this new tool will provide the increased specificity and sensitivity for detection of $M$. cerebralis that are critical to controlling whirling disease among wild trout.

Acknowledgements. This work was supported by the U.S. Department of Interior, Fish and Wildlife Service, Agreement nos. 1445-RM09-97-0014 and AP96-002. Additional support was provided by California Department of Fish and Game, The Whirling Disease Foundation, and Trout Unlimited. This work would not have been possible without Dr Maria E. Markiw, who generously provided the spore material and who has made, with Dr Ken Wolf, such important contributions to our understanding of the phylum Myxozoa. I also thank Terry McDowell for all her assistance with the exposure studies, Kavery Mukkatira for her patient culturng and harvesting of the triactinomyxon stage spores, and Stephane Gresoviac for his assistance with the DNA sequencing

\section{LITERATURE CITED}

Andree KB, Gresoviac SJ, Hedrick RP (1997) Small subunit ribosomal RNA sequences unite alternate actinosporean and myxosporean stages of Myxobolus cerebralis the causative agent of whirling disease in salmonid fish. J Eukaryot Microbiol 44(3):208-215

Andree KB, Gresoviac SJ, Hedrick RP (1998) Relationships among members of the genus Myxobolus (Myxozoa: Bivalvidael based on small subunit ribosomal RNA sequences. J Parasitol (in press)

Antonio DB, Andree KB, MCDowell TS, Hedrick RP (1998) Detection of $M$. cerebralis in rainbow trout (Oncorhynchus mykiss) and oligochaete tissues using a nonradioactive in situ hybridization protocol. J Aquat Anim Health (in press)

Corliss JO (1985) Consideration of taxonomic-nomenclature problems posed by report of Myxosporidians with a twohost life cycle. J Protozool 32(4):589-591

El-Matbouli M, Fischer-Scherl T, Hoffman RW (1992) Present knowledge of the life cycle, taxonomy, pathology, and therapy of some myxosporea spp. important for freshwater fish. Annu Rev Fish Dis 3:367-402

El-Matbouli M, Hoffman RW (1998) Light and electron microscopic study on the chronological development of Myxobolus cerebralis in Tubifex tubifex to the actinosporean stage triactinomyxon. Int J Parasitol 28:195-217

El-Matbouli M, Hoffmann RW, Mandok C (1995) Light and electron microscopic observations on the route of the triactinomyxon-sporoplasm of Myxobolus cerebralis from epidermis into rainbow trout (Oncorhynchus mykiss) cartilage. J Fish Biol 46:919-935
Hamilton AJ, Canning EU (1988) The production of mouse anti-Myxosoma cerebralis antiserum from Percoll-purified spores and its use in immunofluorescent labelling of Historesin-embedded cartilage derived from infected rainbow trout. J Fish Dis 11:185-190

Hedrick RP, Wishkovsky A, Modin JC, Toth RJ (1991) Three myxosporeans found in the cranial and branchial tissue of rainbow trout in California. J Aquat Anim. Health 3 : $55-62$

Höfer B (1903) Ueber die Drehkrankheit der Regenbogenforelle. Allgemeine Fischerei-Ztg. Jahrg XXVIill no. 1, p $7-8$

Hoffman GL (1970) Intercontinental and transcontinental dissemination and transfaunation of fish parasites with emphasis on whirling disease (Myxosoma cerebralis). Dis Fish Shellfish 5:69-81

Iversen ES (1954) A new myxosporidian Myxosoma squamalis, parasite of some salmonid fishes. J Parasitol 40 $397-404$

Janiszewska J (1955) Actinomyxidia: morphology, ecology, history of investigations, systematics, development. Acta Parasitol Pol II:405-443

Kent ML, Margolis L, Corliss JO (1994) The demise of a class of protists: taxonomic and nomenclatural revisions proposed for the protist phylum Myxozoa Grasse, 1970. Can J Zool 72:932-937

Kreier JP (1994) Parasitic Protozoa, 2nd edn, Vol 8. Academic Press, New York

Margolis ML, Kent ML, Bustos P (1996) Diseases of salmonids resembling myxosporean whirling disease, and the absence of Myxosoma cerebralis, in South America. Dis Aquat Org 25:33-37

Markiw ME (1989) Salmonid whirling disease: myxosporean and actinosporean stages cross-react in direct fluorescent antibody test. J Fish Dis 12:137-141.

Markiw ME, Wolf K (1974) Myxosoma cerebralis: isolation and concentration from fish skeletal elements-sequential enzymatic digestions and purification by differential centrifugation. J Fish Res Bd Can 31:15-20

Markiw ME, Wolf K (1978) Myxosoma cerebralis: fluorescent antibody techniques for antigen recognition. J Fish Res Bd Can 35:828-832

Markiw ME, Wolf K (1983a) Myxosoma cerebralis (Myxozoa: Myxosporea) etiologic agent of salmonid whirling disease requires tubificid worm (Annelida: Oligochaetes) in its life cycle. J Protozool 30:561-564

Markiw ME, Wolf K (1983b) Whirling disease of salmonids essential requirements of tubificid oligochaetes in the life cycle of Myxosoma cerebralis. In: Lom J (ed) First International Symposium of Ichthyoparasitology. Parasites and Parasitic Diseases of Fishes. Institute of Parasitology, Agricultural University, Ceské Budęjovice

O'Grodnick JJ (1987) Susceptibility of various salmonids to whirling disease (Myxosoma cerebralis). Trans Am Fish Soc 108:187-190

Sambrook J, Fritsch EF, Maniatis (1989) Molecular cloning: a laboratory manual, 2nd edn. Cold Spring Harbor Laboratory, New York

Schuberg A, Schröder O (1905) Myxosporidien aus dem Nervensystem und der Haut der Bachforelle (Myxobolus neurobius n.sp. und Henneguya nüsslini n.sp.). Arch Protistenkde $6: 47-60$

Shulman SS (1959) Osnovnye napravleniya evolyutsii v otryade Myxosporidia. [Basic trends of evolution in the order Myxosporidia]. Zool Zh 38:1481-1497 (in Russian, English summary)

Thoesen JC (ed) (1994) Suggested procedures for the detec- 
tion and identification of certain finfish and shellfish pathogens, 4 th edn, Version 1. Fish Health Section, American Fisheries Society

Walker PG, Nehring RB (1995) An investigation to determine the cause(s) of the disappearance of young wild rainbow trout in the upper Colorado River, in Middle Park, Colorado. Colorado Division of Wildlife, Department of Natural Resources, Denver, CO

Wolf K (1985) Salmonid whirling disease: status in the United States, 1985. J Wildlife Dis 22:295-299

Wolf K, Markiw ME (1975) Myxosoma cerebralis: serological identification by indirect fluorescent antibody test. Fish Health News 4:8

Editorial responsibility: Wolfgang Körting. Hannover, Germany
Wolf K, Markiw ME (1981) Salmonid whirling disease: new findings indicate that the infective stage produced in and released by tubificid oligochaete is a Triactinomyxon. Fish Health News 10:ii-iv

Wolf K, Markiw ME (1984) Biology contravenes taxonomy in the Myxozoa: new discoveries show alternation of invertebrate and vertebrate hosts. Science 225:1449-1452

Wolf K, Markiw ME, Hiltunen JK (1986) Salmonid whirling disease: Tubifex tubifex (Muller) identified as the essential oligochaete in the protozoan life cycle. J Fish Dis 9:83-85

Wyatt EJ, Pratt I (1963) Myxobolus insidiosus, sp. n., a myxosporidian from the musculature of Oncorhynchus tshawytscha (Walbaum). J Parasitol 49:951

Submitted: February 23, 1998; Accepted: June 26, 1998 Proofs received from author(s): September 21, 1998 